\title{
EFFECT OF MATING AND ITS FREQUENCY ON THE FRUCTOSE CONTENT OF THE COAGULATING GLANDS IN RATS*
}

\author{
D. DRORI, D. AMIR AND Y. FOLMAN \\ Department of Animal Science, Volcani Institute of Agricultural Research, \\ Rehovot, Israel
}

(Received 5th March 1968)

\begin{abstract}
Summary. Male rats mated infrequently had consistently larger coagulating glands containing more fructose than unmated males, and the concentration of fructose in these glands was higher in four out of five experiments. However, males mated frequently had smaller glands and lower fructose content than males mated infrequently.
\end{abstract}

Formation of fructose in the accessory reproductive organs of the male is dependent on androgenic activity (Mann \& Parsons, 1947). Drori \& Folman (1964) have shown that mated male rats have larger accessory reproductive organs than unmated males and suggested that this indicates increased androgenic activity in mated males. This study presents data on the effect of mating and its frequency on fructose content and concentration in the coagulating glands of male rats. The effect of sexual rest on the mated males was also studied.

The general methods used in the present study were identical to those used in the previous one (Drori \& Folman, 1964). Four mated males were raised with two hysterotomized females. In our 'low' and 'medium' frequency mating routines, females were replaced every 3 weeks and once a week, respectively. In the 'high' frequency routine, stilboestrol- and progesterone-injected females replaced three times each week, were used; the males had almost uninterrupted opportunity to copulate. At the end of each experiment the males were killed by ether, the coagulating glands were removed, weighed and frozen. Fructose was estimated according to Mann (1948). To precipitate proteins, however, trichloracetic acid (TCA) according to Erb, Flerchinger, Ehlers \& Gassner (1956) was used in Exps. 1 and 2; and barium hydroxide and zinc sulphate (Ba-Zn) following ethanol, according to Lindner \& Mann (1960) were used in Exps. 3,4 and 5. The TCA method fails to eliminate all the resorcinol-reactive substances which are not fructose. Of the two methods of precipitation, explored on twenty pairs of coagulating glands, the TCA method consistently yielded $28 \%$ more resorcinol-reactive substances than the Ba- $\mathrm{Zn}$ method. The correlation coefficient between the two sets of values obtained by these methods was $r=0.97$. The Ba-Zn method is considered specific for fructose.

\footnotetext{
* Contribution from the Volcani Institute of Agricultural Research (N.U.I.A.), Rehovot, Israel. 1967 Series; No. 1254E.
} 
Five experiments were performed. In Exp. 1, thirteen pairs of male littermates were divided into two groups; one group was mated at 'low' frequency and the other was unmated. All rats were killed at 286 days of age. In Exp. 2, ten groups of three littermates were used and one littermate from each allocated to three groups. One group was mated at 'low' frequency and two groups were left unmated; in one of the two unmated groups, however, the males were housed in groups of four per cage, and in the other they were raised singly. Males of the latter two groups were permitted to copulate eight times between 60 and 460 days of age, but only in controlled tests of fertility and sexual behaviour. Two males died of disease; the surviving twenty-eight males were killed at 484 days of age. In Exp. 3, twelve groups of four littermates were used

\section{TABLE 1}

FRUGTOSE AND RESORGINOL-REAGTIVE SUBSTANGES IN THE GOAGULATING GLANDS OF MATED AND UNMATED MALE RATS (MEANS \pm S.E.)

\begin{tabular}{|c|c|c|c|c|c|c|}
\hline \multirow{2}{*}{ Experiment } & \multirow{2}{*}{$\begin{array}{c}\text { Frequency } \\
\text { of } \\
\text { mating }\end{array}$} & \multirow{2}{*}{$\begin{array}{c}\text { No. } \\
\text { of } \\
\text { males }\end{array}$} & \multirow{2}{*}{$\begin{array}{c}\text { Weight of } \\
\text { coagulating } \\
\text { glands } \\
\text { (mg) }\end{array}$} & \multirow{2}{*}{$\begin{array}{c}\text { Method of } \\
\text { deproteinization }\end{array}$} & \multicolumn{2}{|c|}{ Fructose equivalent } \\
\hline & & & & & $\begin{array}{c}\text { Content } \\
(\mu g)\end{array}$ & $\begin{array}{c}\text { Concentration } \\
(\mu \mathrm{g} / \mathrm{mg})\end{array}$ \\
\hline 1 & $\begin{array}{l}\text { Low } \\
\text { Unmated }\end{array}$ & $\begin{array}{l}13 \\
13\end{array}$ & $\begin{array}{r}166 \pm 7^{x} \\
97 \pm 10^{y}\end{array}$ & TCA & $\begin{array}{l}313 \pm 36^{a} \\
206 \pm 48^{\circ}\end{array}$ & $\begin{array}{l}1.88 \pm 0.17 \\
1.85 \pm 0.25\end{array}$ \\
\hline 2 & $\begin{array}{l}\text { Low } \\
\text { Unmated } \\
\text { Unmated* }\end{array}$ & $\begin{array}{r}10 \\
8 \\
10\end{array}$ & $\begin{array}{l}155 \pm 10^{\mathrm{a}} \\
135 \pm 6 \\
119 \pm 11^{\mathrm{b}}\end{array}$ & TCA & $\begin{array}{l}430 \pm 58^{\mathrm{a}} \\
320 \pm 28 \\
244 \pm 45^{\mathrm{b}}\end{array}$ & $\begin{array}{l}2.69 \pm 0.20^{\mathrm{a}} \\
2.39 \pm 0.21 \\
1.94 \pm 0.28\end{array}$ \\
\hline 3 & $\begin{array}{l}\text { High } \\
\text { Medium } \\
\text { Low } \\
\text { Unmated }\end{array}$ & $\begin{array}{l}12 \\
12 \\
12 \\
12\end{array}$ & $\begin{array}{l}147 \pm 6 \\
160 \pm 4^{\mathrm{a}} \\
162 \pm 9^{\mathrm{a}} \\
122 \pm 9^{\mathrm{b}}\end{array}$ & $\mathrm{Ba}-\mathrm{Zn}$ & $\begin{array}{l}229 \pm 16^{y} \\
308 \pm 42^{y} \\
463 \pm 47^{x} \\
254 \pm 38^{y}\end{array}$ & $\begin{array}{l}1 \cdot 55 \pm 0.09^{y} \\
1 \cdot 84 \pm 0 \cdot 14^{y} \\
2 \cdot 81 \pm 0 \cdot 23^{x} \\
2 \cdot 02 \pm 0.21^{y}\end{array}$ \\
\hline 4 & $\begin{array}{l}\text { Hight } \\
\text { Low } \dagger \\
\text { Unmated }\end{array}$ & $\begin{array}{l}12 \\
12 \\
12\end{array}$ & $\begin{array}{l}158 \pm 11^{x} \\
147 \pm 9 \\
128 \pm 11^{y}\end{array}$ & $\mathrm{Ba}-\mathrm{Zn}$ & $\begin{array}{l}384 \pm 47 \\
397 \pm 50^{\mathrm{a}} \\
297 \pm 44^{\mathrm{b}}\end{array}$ & $\begin{array}{l}2.38 \pm 0.21 \\
2.64 \pm 0.21 \\
2.25 \pm 0.21\end{array}$ \\
\hline 5 & $\begin{array}{l}\text { High } \\
\text { Hight } \\
\text { Low } \\
\text { Low† } \\
\text { Unmated }\end{array}$ & $\begin{array}{l}12 \\
12 \\
12 \\
12 \\
12\end{array}$ & $\begin{array}{l}156 \pm 6^{\mathrm{b}} \\
178 \pm 12^{\mathrm{a}} \\
175 \pm 12 \\
183 \pm 7^{\mathrm{a}} \\
154 \pm 7^{\mathrm{a}}\end{array}$ & $\mathrm{Ba}-\mathrm{Zn}$ & $\begin{array}{l}106 \pm 12^{y} \\
320 \pm 31^{x} \\
367 \pm 35^{x} \\
339 \pm 21^{x} \\
334 \pm 31^{x}\end{array}$ & $\begin{array}{l}0.67 \pm 0.06^{y} \\
1 \cdot 78 \pm 0.07^{x} \\
2 \cdot 05 \pm 0.11^{x} \\
1 \cdot 85 \pm 0.07^{x} \\
2 \cdot 15 \pm 0.14^{x}\end{array}$ \\
\hline
\end{tabular}

Significant differences are indicated by superscripts; $a, b$ and $x, y$ denote differences significant at $P \leqslant 0.05$ and $P \leqslant 0.01$, respectively.

* Raised singly.

† Unmated during 7 days before killed.

and one littermate from each allocated to four groups; these were mated at 'high', 'medium' or 'low' frequency, or left unmated to 90 days of age and killed. In Exp. 4, twelve groups of three littermates were allotted to three groups; one was mated at 'high' and one at 'low' frequency to 83 days of age and rested till 90 days; the third group was unmated. All were killed at 90 days. In Exp. 5, twelve sets of five littermates were split into five groups. Two groups were mated at 'high' and two at 'low' frequency. One 'high' and one 'low' group were mated till 83 days and then rested but the other 'high' and the other 'low' group were mated till 90 days of age. The fifth group was unmated. All were killed at 90 days of age. 
The mean weights of the coagulating glands, and the content and concentration of fructose (or that of fructose plus other resorcinol-reactive substances in Exps. 1 and 2) of all groups are presented in Table 1.

The content of fructose in the coagulating glands was highest in the groups mated at 'low' frequency in all five experiments, and the fructose concentration was highest in the same groups in four experiments. Four out of five differences in fructose content and two out of four in concentration, between the 'low' and the unmated control groups, were significant.

At the same time, 'high' versus 'low' frequency of mating reduced the content and concentration of fructose (Exp. 3), which, however, increased rapidly when 'high' frequency males were left unmated for 7 days before being killed (Exps. 4 and 5). It appears that the inverse relationship between fructose level in the coagulating glands and the frequency of mating in mated males, is due to the frequent evacuation of the secretion and the preponderance of fructose in the secretion rather than in the glandular tissue.

Harvey (1948) has already emphasized the importance of the interval since previous emission in interpreting fructose determinations in human semen. If the rate of the fructose production in mated and unmated male rats were equal, one would expect to find less fructose in the glands of mated males, because ejaculation evacuates the glands. Since male rats mated at low frequency had consistently more fructose in their coagulating glands, the conclusion is warranted that they produce more fructose than unmated males. These data support the hypothesis of increased androgenic activity in mated male rats.

\section{REFERENCES}

Drori, D. \& Folman, Y. (1964) Effects of cohabitation on the reproductive system, kidneys and body composition of male rats. F. Reprod. Fert. 8, 351.

Erb, R. E., Flerchinger, F. H., Ehlers, M. H. \& Gassner, F. X. (1956) Metabolism of bull semen. II. Fructolysis relationships with sperm concentration and fertility. 7. Dairy Sci. 39, 326.

Harvey, C. (1948) Relation between the volume and fructose content of human semen. Nature, Lond. $162,812$.

LindNeR, H. R. \& MANN, T. (1960) Relationship between the content of androgenic steroids in the testes and the secretory activity of the seminal vesicles in the bull. 7. Endocr. 21, 341.

Mann, T. (1948) Fructose content and fructolysis in semen. Practical application in the evaluation of semen quality. 7. agric. Sci. 38, 323.

Mann, T. \& Parsons, U. (1947) Effect of testicular hormone on the formation of seminal fructose. Nature, Lond. 160, 294. 